\title{
Progress in Phases 2 and 3 of the Photovoltaic Manufacturing Technology Project (PVMaT)
}

C. E. Witt, R. L. Mitchell, G. D. Mooney National Renewable Energy Laboratory L. O. Herwig U.S. Department of Energy D. Hasti

Sandia National Laboratories

R. Sellers

Solar Energy Industries Association

\section{Presented at the} 23rd IEEE Photovoltaic Specialists Conference May 9-14, 1993 Louisville, Kentucky

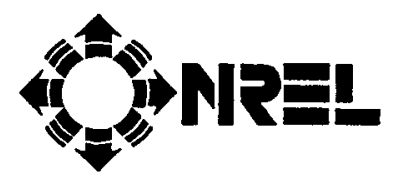

National Renewable Energy Laboratory 1617 Cole Boulevard Golden, Colorado 80401-3393 A national laboratory operated for the U.S. Department of Energy under contract No. DE-AC02-83CH10093

Prepared under Task No. PV350101

October 1993 


\section{NOTICE}

NOTICE: This report was prepared as an account of work sponsored by an agency of the United States government. Neither the United States government nor any agency thereof, nor any of their employees, makes any warranty, express or implied, or assumes any legal liability or responsibility for the accuracy, completeness, or usefulness of any information, apparatus, product, or process disclosed, or represents that its use would not infringe privately owned rights. Reference herein to any specific commercial product, process, or service by rade name, trademark, manufacturer, or otherwise does not necessarily constitute or imply its endorsement, recommendation, or favoring by the United States government or any agency thereof. The views and opinions of authors expressed herein do not necessarily state or reflect those of the United States government or any agency thereof.

Printed in the United States of America

Available from:

National Technical Information Service

U.S. Department of Commerce

5285 Port Royal Road

Springfield, VA 22161

Price: Microfiche A01

Printed Copy AO2

Codes are used for pricing all publications. The code is determined by the number of pages in the publication. Information pertaining to the pricing codes can be found in the current issue of the following publications which are generally available in most libraries: Energy Research Abstracts (ERA); Government Reports Announcements and Index (GRA and I); Scientific and Technical Abstract Reports (STAR); and publication NTIS-PR-360 available from NTIS at the above address. 


\title{
PROGRESS IN PHASES 2 AND 3 OF THE PHOTOVOLTAIC MANUFACTURING TECHNOLOGY PROJECT (PVMAT)
}

\author{
C. Edwin Witt, Richard L. Mitchell, G. David Mooney, \\ Lloyd O. Herwig, ${ }^{1}$ David Hasti, ${ }^{2}$ Rick Sellers ${ }^{3}$ \\ National Renewable Energy Laboratory, Golden CO 80401 \\ 'U.S. Department of Energy \\ 2Sandia National Laboratories \\ ${ }^{3}$ Solar Energy Industries Association
}

\begin{abstract}
The first year of the process-specific activities of the Photovoltaic Manufacturing Technology (PVMaT) project has been completed, and the first subcontracts for teamed efforts on R\&D of a general nature have been awarded. A second solicitation for process-specific research and development (R\&D) is in the evaluation stage for award of subcontracts. This paper describes the technical accomplishments of the first process-specific subcontracts (Phase 2A), the status of the teamed research (Phase 3A), and the status of the solicitation for the second process-specific solicitation (Phases 2B).
\end{abstract}

ABSTRACI

\section{INTRODUCTION}

As has been described previously [1], the Photovoltaic Manufacturing Technology project (PVMaT) is a government/ industry $R \& D$ partmership composed of joint efforts between the federal government (through the U.S. Department of Energy) and members of the U.S. photovoltaic (PV) industry. The project's immediate goal is to assist U.S. industry in retaining and extending its world leadership role in the manufacture and commercial development of PV components and systems. PVMaT is designed to do this by helping the U.S.PV industry improve manufacturing processes, accelerate manufacturing cost reductions for PV modules, improve commercial product performance, and lay the groundwork for a substantial scale-up of U.S.-based PV manufacturing plant capacities.

PVMaT is being carried out in three separate phases, each designed to address separate research and developent (R\&D) requirements for achieving PVMaT goals. Phase 1 was a problemidentification phase of about 3-months duration. In Phase 1, the status and needs of the U.S. PV manufacturing industry were identified, and the development of Phase 2 procurement responsive to the industry's needs was initiated. Phase 1 was completed in 1991.

Phase 2, the problem solution phase, which addresses process-specific problems of specific manufacturers, is now under way with an expected duration of 5 years. The first solicitation under this phase (PVMaT 2A) was open only to those organizations that received awards in the Phase 1 solicitation, and seven resulting subcontracts were implemented in early 1992 . The subcontracts are cost-shared between the U.S. government and U.S. industrial participants. Technical accomplishments for the first year of PVMaT 2A are presented below. Proposals for a second, overlapping, and similar process-specific solicitation (PVMaT 2B) were due in September of 1992. This second Phase 2solicitation is in the evaluationstage, with awards planned for later this year. PVMaT $2 \mathrm{~B}$ was open to all U.S. PV industrial firms, thus giving organizations that were not ready for the first Phase 2 procurement cycle another chance to "ramp on" and participate in the solution phase of the program.

Phase 3 addresses R\&D problems that are relatively common to a number of PV companies or the PV industry as a whole. These "generic" problem areas are being addressed through a teamed-research approach. A solicitation (Phase 3A) for these teamed research efforts was released in October 1991. Two subcontracts for Phase 3A have recently been awarded. These research organizations are focusing on module-related $R \& D$ problems found to be common to a significant set of PV manufacturers, and these subcontract activities are described below.

\section{PVMaT PROGRESS}

Phase 2A

The winners in PVMaT $2 A$ are listed in the Table 1 below. Following Table 1 is a description of the seven subcontractor projects and their first year PVMaT accomplishments.

Siemens Solar Industries Photovoltaic $\mathrm{C}_{2}$ Silicon Manufacturing Technology Improvements -Siemens Solar Industries (SSI) is improving $\mathrm{Cz}$ Si-ingot quality; increasing the materials use efficiency for crystalline-silicon (c-Si) wafer sawing; investigating improvements in device processing; investigating the introduction of automation to a significant portion of their c-Si module manufacturing lines; and reducing the amount of hazardous waste gener- 
Table 1: PVMaT Phase 2A Participants

\section{Subcontractor}

Siemens Solar Industries Camarillo, Califomia

Solarex Corporation

Newtown, Pennsylvania

Mobil Solar Energy

Corporation

Billerica, Massachusetts

ENTICH, Inc.

Dallas, Texas

AstroPower, Inc.

Newark, Delaware

Utility Power Group

Chatsworth, California

Energy Conversion Devices Troy, Michigan
Subcontract Title

Photovoltaic Cz Silicon Manufacturing Technology Improvements

Large-Area, Triple-Junction, a-Si Alloy Production Scale-Up Project

Thin Edge-Defined Film-Fed Growth (EFG) Octagons

Photovoltaic Manufacturing Technology (PVMaT) Improvements for ENTECH's Concentrator Module

Silicon-Film Photovoltaic Manufacturing Technology

a:Si Photovoltaic Manufacturing TechnologyPhese 2A

Continuous Roll-to-Roll Amorphous Silicon Photovoltaic Manufacturing Technology
Principal

Investigator

T. Jester

R. Oswald

J. Kalejs

M. O'Neill

W. Bottenberg

G. Duran

M. Izu ated. This effortisbeingaddressed in three 1-yearphases. Successful implementation of this program will result in decreasing SSI's c-Si module cost by more than half while doubling its U.S. manufacturing capability. SSI's accomplishments during the first phase of this subcontract include an increase in wire-saw production capacity by over $30 \%$ due to reduced kerf loss and thinner wafer processing; an increase in crystal-growth yields through polysilicon studies; elimination of Freon and replacement with a no-clean solder paste in SSI's module production by April 1993; and incorporation of graphite design changes into the SSI's crystal growers, resulting in a $30 \%$ cost savings ( $\$ 300 \mathrm{~K} / \mathrm{yr}$ ).

Solarex Corporation Large-Area, Triple-Junction, a-Si Alloy Production Scale-Up Project - Solarex Corporation is improving the deposition and quality of its transparent front contact; optimizing its laser patterning process; scaling up the semiconductor deposition process; improving the back contact deposition; and scaling up and improving the encapsulation and testing of its a-Si:H modules. Successful implementation of this 3-year program will result in Solarex producing $20.56-\mathrm{m}^{2}\left(6-\mathrm{ft}^{2}\right), 10 \%$ stabilized efficiency, 75-W a-Si:H modules with a total overall module yield of 275\%. At a proposed production capacity of $10 \mathrm{MW} / \mathrm{year}$, this would result in a potential cost reduction from the present price of $\$ 11.05 / \mathrm{W}_{p}$ to $\$ 1.14 / \mathrm{W}_{\mathrm{p}}$. Solarex's accomplishments during the first phase of this subcontract include; the design of an $20.56-\mathrm{m}^{2}$ (6- $\left.\mathrm{ft}^{2}\right)$ plasma-enhanced chemical vapor deposition (PECVD) a-Si:H based deposition system; completion of light soaking tests; demonstration of a new laser-scribing system that does not cause module failures in the wet hi-pot tests; and the fabrication of a Frit Dispenser used in Solarex module fabrication.
Mobil Solar Energy Corporation Thin Edge-Defined Film-Fed Growth (EFG) Octagons -Mobil Solar Energy Corporation (MSEC) is reducing the cost of solar cell processing through a 50\% reduction in its EFG Si-wafer thickness; increasing the throughput of the laser-cutting of the wafers; increasing the mechanical strength, and thus yield, of the wafers; and evaluating integrated computer-aided manufacturing control programs for the MSEC crystal growth manufacturing line to enhance productivity. Successful implementation of this 3-year program will allow Mobil Solar to produce octagonal Si tubes, producing 200- $\mu$ m-thick Si wafers with a thickness variation of $\pm 50 \mu \mathrm{m}$. The previous minimum wafer thickness for this process was $400 \mu \mathrm{m}$. MSEC will also develop laser wafer-cutting capabilities resulting in the processing of 12 wafers per minute. Its accomplishments during the first phase of this subcontract include testing and analysis that indicate potential materials cost reductions of $15 \%$ due to wafer thickness, $10 \%$ due to wafer flatness improvement, and $25 \%$ due to a growth rate; completing specifications for a factory prototype EFG octagon crystal growth furnace for $300-\mu \mathrm{m}$-thick Si wafers; designing and testing a laser cutting station that will increase pilot production line throughput by a factor of two; and demonstration of the cutting feasibility of silicon wafers near the low-damage threshold with a 585-nm high-power dye laser.

ENTECH, Incorporated Photovoltaic Manufacturing Technology Improvements for ENTECH's Concentrator Module ENTECH is automating a significant portion of its manufacturing line, aiding key ENTECH vendors in improving the vendors' 
technologies; scaling up the ENTECH manufacturing line to accommodate large volume production; and addressing ES\&H issues throughout all of the associated manufacturing processes. The effort is being addressed in two 1-year phases. Successful implementation of this program will result in an initial linear concentrator module manufacturing plant with the capability of producing PV modules at a rate of $10 \mathrm{MW} / \mathrm{yr}$. ENTECH's accomplishments during the first phase of this subcontract include; the development of laboratory prototype work stations for PV cell assemblies and receivers; the identification and delivery of process-compatible advanced-cell samples from four separate vendors; the development of an improved prismatic lens cover for cells that resulted in a 90\% reduction in both material and labor costs for that step; the development of a continuous, prelaminated, rolledFresnel lens that resulted in both a $20 \%$ materials cost reduction and the elimination of solvent use in the ENTECH process; and development of ribbon solder techniques that have resulted in an $80 \%$ reduction in materials costs with additional savings in labor.

AstroPower, Incorporated Silicon-Film Photovoltaic Manufacturing Technology - AstroPower is enhancing its Silicon-

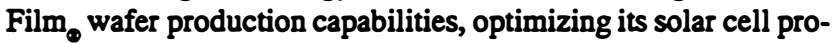
cessing, and improving the polycrystalline silicon-film module assembly portion of its manufacturing line. Successful implementation of this 3-year program willresult in an upgrade to AstroPower's facility that will allow it to reach a production rate of $19 \mathrm{MW} / \mathrm{yr}$ of $1.22-\mathrm{m}^{2}$ polycrystalline silicon modules with an output of $170 \mathrm{~W}$ each by the mid-1990s. AstroPower's accomplishments during the first phase of this subcontract include the demonstration an $8.8 \%$

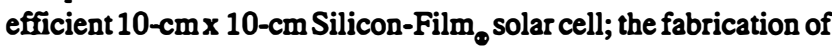
the first $15-\mathrm{cm} \times 45-\mathrm{cm}$ Silicon-Film $\mathrm{m}_{\odot}$ cell (the largest solar cell ever produced); the demonstration of a 0.48-MW/yr Silicon-Film machine operation rate, and $74 \%$ silicon feedstock use efficiency; the initial planning for 2.4-MW/year wafer fabrication machine; and planning for the introduction of new 225- $\mathrm{cm}^{2}$ Silicon-Film solar cell product in 1993.

Utility Power Group a:Si Photovoltaic Manufacturing Technology - Phase 2A - The Utility Power Group (UPG) is conductingresearch on encapsulation of their a-Si:H modules, with consideration given to approaches that do not require a second glass layer, and automation of module termination. Additionally, UPG's lower-tier subcontractor, Advanced Photovoltaic Systems (APS), is optimizing the automation of its Eureka manufacturing line; improving the encapsulation of the Eureka ${ }_{\oplus}$ module, and introduc- ingreal-time processing and quality control to the Eureka production line. Successfulimplementation of this 3-year effort will result in increasing the module manufacturing yield over the current level by $35 \%$ while decreasing the direct cost by about $25 \%$. The accomplishments of the UPG-APS team during the first phase of this subcontract include the completion of POWERGLASS module qualification testing for candidate encapsulation materials; reduced POWERGLASS module termination and encapsulation manufacturing costs by 50\%; the introduction of three new Eureka module products ( $25-\mathrm{W}$ and $50-\mathrm{W}$ products for $12-\mathrm{V}$ applications); completion of the automation of about $60 \%$ of the Eureka ${ }_{\oplus}$ production encapsulation line; and completion of a design for full-scale enhanced Eureka modules.

Energy Conversion Devices, Incorporated Continuous Roll-to-RollAmorphousSilicon Photovoltaic Manufacturing Technology - Energy Conversion Devices (ECD) is developing the production of 0.3-m x 1.22-m (1-ft x 4-ft) triple-junction a-Si-Ge alloy modules with $11 \%$ stable efficiency, reducing its manufacturing costs through utilization of its high deposition rate techniques to enhance the production throughput, and reducing material and labor costs. The effort is being addressed in three 1-year phases. Successful implementation of this program will allow ECD to work toward an ultimate goal of building a $100-\mathrm{MW} / \mathrm{yr}$ roll-to-roll, automated a-Si module manufacturing facility. At this anticipated pruduction capacity, ECD could reduce the cost of PV-generated electricity to less than $\$ 1.00 / W_{p}$. ECD's accomplishments during the first phase of this subcontract include completion of improvements to the ECD a-Si-Ge alloy deposition system, establishing the first roll-to-roll a-Si-Ge production line facility; demonstration of 7.2\% stabilized efficiency on $21.22-\mathrm{m}\left(4-\mathrm{ft}^{2}\right)$ triple-junction a-Si alloy modules; and significant efforts toward increasing the effective manufacturing throughput.

\section{Phase 3A}

The winners in PVMaT 3A are listed in the Table 2 below. Both contracts began in early January 1993. Following Table 2 is a description of the seven subcontractor projects.

Spire Corporation Automated Solar Cell AssemblyTeamed Process Research - Spire will conduct manufacturing R\&D to improve crystalline and polycrystalline Si PV module manufacturing processes with a goal of substantially reducing module manufacturing costs. Areas that will be addressed include processing

Table 2: PVMaT Phase 3A Participants

Subcontractor Subcontract Title

Principal

Investigator

\begin{tabular}{lll}
$\begin{array}{l}\text { Spire Corporation } \\
\text { Bedford, Massachusetts }\end{array}$ & Automated Solar Cell Assembly Teamed Process Research & M. Nowlan \\
\hline $\begin{array}{l}\text { Springborn Laboratories, } \\
\text { Inc. }\end{array}$ & Photovoltaic Manufacturing Technology (PVMaT) & W. Holley \\
Enfield, Connecticut & &
\end{tabular}


rates, process control, yield, throughput, material utilization efficiency, and increased use of automation. These issues are being addressed for thin ( $\leqslant 200-\mu \mathrm{m})$ silicon wafers. To conduct these efforts, Spire will team with Solec International (a PV module manufacturer) and the University of Massachusetts-Lowell/Center for Productivity Enhancement (automation specialists) who will act as lower-tier subcontractors. The effort is being addressed in two, 1-year phases.

Springborn Laboratories Photovoltaic Manufacturing Technology (PVMaT) - Springborn will try to solve problems related to the PV module encapsulant ethylene-vinyl-acetate(EVA) discoloration and/or degradation. Areas that will be addressed include a case history study and problem definition, identification of discoloration and/or degradation mechanisms, development of
EVA-stabilization strategies, accelerated testing of new laminates, and pilot scale production and field-testing of new laminates. To conduct these efforts, Springborn is teaming with the SSI; Photocomm, Inc.; United Solar Systems Corp.; Solarex Corp.; Texas Instruments; Solec International, Inc.; UPG; APS; Global Photovoltaic Specialists, Inc.; Arizona State University; Arizona Public Service Company; and the University of Connecticut. The effort is being addressed in three 1-year phases.

\section{REFERENCES}

1. C.E. Witt, L.O. Herwig, R. Mitchell, and G.D. Mooney. Status of the PhotovoltaicManufacturing Technology (PVMaT) Project. Proc. 22nd IEEE PVSC, Las Vegas, NV (1991). 